\title{
Constitutional Amendments: Making, Breaking, and Changing Constitutions, by Richard Albert, Oxford University Press, 2019**
}

\section{Constitutional Amendments and Democracy: A View from Latin America}

\author{
INTRODUCTION
}

In his pathbreaking book Constitutional Amendments: Making, Breaking, and Changing Constitutions, Professor Richard Albert studies the "uncharted terrain" of amendment rules. He maps the "intellectual topography of constitutional amendment rules" and, at the same time, tries to answer "the many questions about amendment that have until now remained unanswered" ${ }^{1}$. In particular, Professor Albert "devote(s) much of the book to a question for which there are surprisingly few comprehensive answers in the scholarly literature: how should be design the rules of constitutional amendments"2.

The outcome is an elegant, comprehensive and profound study, which draws from "comparative, doctrinal, historical, and theoretical perspectives"3. The author presents a clear and easy-to-read study, which he illustrates through examples of pressing importance that help us understand the enormous relevance of the book's main theme. Clearly, Albert's work represents the most complete and up-to-date guide for the study of constitutional amendments.

Before proceeding to an examination of the book, let me clarify three points about the review that follows. In the first place, I am not going to carry out an exhaustive analysis of Constitutional Amendments, but rather focus on a

* Doctor of Law from the University of Buenos Aires (UBA) and Doctor of Jurisprudence from the University of Chicago. Correo de contacto: roberto.gargarella@gmail.com. ORCID ID: https://orcid.org/0000-0003-1579-5427.

** Recibido el 26 de febrero del 2020, aprobado el 31 de agosto del 2020.

Para citar el artículo: Constitutional Amendments: Making, Breaking, and Changing Constitutions, by Richard Albert. En Revista Derecho del Estado, Universidad Externado de Colombia. N. ${ }^{\circ} 48$, enero-abril de 2021, 371-389.

DOI: https://doi.org/10.18601/01229893.n48.13

1 Albert, Richard. Constitutional Amendments: Making, Breaking, and Changing Constitutions. Oxford: Oxford University Press, 2019, p. 30.

2 AlBERT, Richard. Author Interview: Constitutional Amendments: Making, Breaking, and Changing Constitutions, 2019. Available in: https://blog-iacl-aidc.org/just-published/2019/10/15/ author-interview-constitutional-amendments-making-breaking-and-changing-constitutions.

3 Albert, Richard. Constitutional Amendments: Making, Breaking, and Changing Constitutions. Oxford: Oxford University Press, 2019, p. 3. 
few topics that I consider of particular relevance. Secondly, the critical view that I shall assume as my standpoint will be based on a specific theory of democracy, namely a "dialogic conception of democracy". Thirdly, most of the examples I shall consider will come from recent Latin American history. I believe that these rich regional examples, which do not play a prominent role in Professor Albert's book, may be of great help in order to "test" and challenge many of the claims that the author makes thorough the book.

\section{IN PRAISE OF (DEMOCRATIC) THEORY}

In the introduction of his book, Professor Albert declares that the two main purposes of his work are i) "to inspire interest in constitutional amendment;" and ii) "to guide those seeking to understand how constitutions change". When one finishes reading Constitutional Amendments, it becomes clear that the author managed to achieve his main objectives: the book does generate interest in constitutional amendment and provides an attractive guide to those seeking to understand how constitutional change works. Now, Professor Albert does many other things in his book, besides providing a map for guiding legal reformers in the sub-explored territory of constitutional amendments: he suggests that "codified unamendability" is a bad idea; he maintains that certain forms of judicial review for constitutional amendments are problematic; he discusses the important doctrine of "unconstitutional constitutional amendments;" he rejects both "formal rigidity" and "hyper flexibility"; and he finally claims that the rules of change should "keep the constitution stable and true to popular values yet always changeable when necessary" .

I tend to agree with most of Albert's opinions in these matters, although it is difficult to properly see where these opinions derive from. As his celebrated Edmund Burke could have put it: we need his judgements rather than his opinions on the matter. In other words, we need Professor Albert to articulate the theory that is "doing the work" behind his important suggestions and critiques. ${ }^{6}$ Unfortunately, it is not easy to find the theoretical sources that give support to such claims, because the author never clearly reveals what the theoretical foundations of his work are. As a result of this, by the end of the book, we get an excellent map of the "uncharted terrain" of constitutional amendments, but we remain with few reasons to go one way or the other. Therefore -I would suggest- Professor Albert needs to present more clearly

\footnotetext{
$4 \quad$ Ibid., p. 36.

5 Ibid., p. 271

6 Paraphrasing Ronald Dworkin (and Kant) I would say that a comparative study of amendments "without theory is blind [...] (a comparative study may become) a way of stating a conclusion, not a way of reaching one, and theory must do the real work" (DWORKIN, RoNALD. In praise of theory. In: Arizona State Law Journal, n. ${ }^{\circ} 353,1997$, p. 372).
} 
what the theoretical foundations of his views are. More particularly -I would add- the author needs to tell us what his understanding of democracy is.

In fact, democratic theory seems indispensable, not only with regard to the more general and fundamental questions in the area (say, where does the legitimacy of a Constitution come from? Can the "old generations" limit the "new ones"? Can a democratically adopted Constitution be reformed and, in that case, under what requirements?), ${ }^{7}$ but also, and more significantly, regarding the problems Professor Albert is more concerned about (i.e., matters related to amendability and unamendability; judicial review of amendments; alternatives to judicial review; etc.).

Trying to contribute to this important theoretical enterprise, in what follows I shall approach to Constitutional Amendments with the help of a particular view of democracy, which can be characterized by two fundamental features, namely i) its "dialogic" content, and ii) its contextual character. Let me briefly explain each of those features.

i) A theory of democracy. The theory of democracy that I shall here consider is (a specific version of) a dialogic or deliberative approach. As we all know, there is a long discussion concerning the meaning, scope, implications and virtues of deliberative democracy, but at this point I will only refer to certain aspects of that complex discussion ${ }^{8}$. According to the understanding of democracy that I shall here assume, public decisions gain justification when they are adopted after an ample process of collective discussion with all those potentially affected $^{9}$. In other words, for this version of deliberative democracy, democracy is based on two fundamental pillars, namely discussion and social inclusion. As Habermas put it, in a recent interview, the procedure of a deliberative democracy "requires, on the one hand, the inclusion of all of those affected by the democratic decisions and, on the other, it makes these decisions dependent on the more or less discursive character of the preceding deliberations" ${ }^{10}$.

7 A good example of such an approach may be found in Elster, Jon, SLAgStad, Rune. Constitutionalism and Democracy. Cambridge: Cambridge University Press, 1988. In particular, see Holmes, Stephen. “Precommitment and the Paradox of Democracy," in Elster, Jon, Slagstad, Rune. Constitutionalism and Democracy. Cambridge: Cambridge University Press, 1988.

8 Bohman, James. Public Deliberation: Pluralism, Complexity, and Democracy. Cambridge: mit Press, 1996, Bohman, James, Rehg, William (eds.). Deliberative Democracy. Cambridge: mit Press, 1997, Elster, Jon (ed.). Deliberative democracy. Cambridge: Cambridge University Press, 1998, Gutmann, Amy \& Thompson, Dennis. Why Deliberative Democracy? Princeton: Princeton University Press, 2004, Habermas, JuRgen. Between Facts and Norms: Contributions to a Discourse Theory on Law and Democracy. Cambridge: mit Press, 1996, Nino, CARLos. The Constitution of Deliberative Democracy. New Haven: Yale University Press, 1997.

9 Habermas, Jurgen. Between Facts and Norms: Contributions to a Discourse Theory on Law and Democracy. Cambridge: MIT Press, 1996.

10 Habermas, Jurgen. "Interview with Jurgen Habermas," in B ACHTIGER, Andre, DryzeK, JoHn et al., The Oxford Handbook of Deliberative Democracy, Oxford: Oxford University Press, 2018 , p. 873. 
I understand that, for some scholars, the regulatory ideal of a "dialogic democracy" may result too demanding and too abstract. In my opinion, however, such ideal only refines some intuitions we all have about what is required of a decision to be considered a justified decision. We find a good example of what I am saying in the same book under examination. In fact, in different passages of Constitutional Amendments, Professor Albert seems to suggest that his work is founded on a certain theory of democracy, which seems closely related to what I called a dialogic or deliberative theory of democracy. For instance, he admits that a constitutional change is more difficult to justify when it has been carried out "without sufficient deliberation or popular support" ${ }^{11}$; and praises certain "alternative" forms of judicial review of amendments "built on the theory of democratic dialogue" 12 , which he presents and defends as a variation on the New Zealand Bill of Rights Act for the judicial review of statutes"13.

He even closes the book with a section dedicated to democracy, and makes a particular statement saying that the decision to amend the constitution should reflect "the considered judgment of the community and the sociological legitimacy that only deliberative procedures can confer" ${ }^{\prime 14}$. All these are crucial claims about crucial questions through which Professor Albert shows his clear sympathies towards a dialogic theory of democracy. This is important, although -I submit- his views about democratic theory should be made more explicit, and then refined and strengthened. In that way, I believe, his approach to the topic of constitutional amendments would gain a lot -as I will try to demonstrate- in both its capacity to understand and critically evaluate the present situation on the matter.

ii) An historically situated approach. Let me now examine the second element that characterizes my theoretical standpoint, namely its contextual sensitivity. As anticipated, the selected dialogic theory will be informed by the "dramas" that characterize the present historical moment. This historical situation -I submit- can be characterized by the presence of a renewed and unprecedented crisis affecting the heart of the traditional system of "checks and balances": I am referring to the (so-called) problem of "democratic erosion." Of course, a proper discussion of the issue results impossible at this point, but for the limited purposes of this review, it may suffice to say the following. There seems to be a widespread agreement among political theorists and constitutional doctrinaires about the fact that we are going through

11 Albert, Richard. Constitutional Amendments: Making, Breaking, and Changing Constitutions. Oxford: Oxford University Press, 2019, p. 221-2.

12 Ibid., p. 223.

13 Ibid., p. 223.

14 Ibid., p. 270. 
a particularly severe and profound democratic crisis ${ }^{15}$. Scholars have referred to this phenomenon in different ways (i.e., "democratic erosion"; "democratic backsliding"; "democratic fatigue"; "democratic extortion") but they all seem to agree on the depth and breadth of a crisis that does not seem easy to overcome through traditional methods.

In the book they dedicated to the topic of "democratic erosion", Ginsburg and Huq have distinguished between "authoritarian collapse", which they present as "a rapid, wholesale turn away from democracy," and "democratic erosion", which they describe as "the risk of slow, but ultimately substantial unraveling along the margins of rule-of-law, democratic, and liberal rights" 16 . "Democratic erosion" would imply a "process of incremental but ultimately still substantial, decay in the three basic predicates of democracy - competitive elections, liberal rights to speech and association and the rule of law, across different institutions, against a baseline of some ingoing level of democracy". ${ }^{17-18}$

Having this theoretical perspective in mind, we can now go back to the topic of constitutional amendments and re-examine some of Professor Albert's main claims. As we shall see, this reinvigorated democratic approach may help us to greatly improve our study of constitutional amendments. In fact, when we begin to think of constitutional amendments as deliberative practices that concern the entire citizenry, some of the main aspects of Professor Albert's analysis on the subject begin to change. For example, the doctrine of unconstitutional constitutional amendments needs now to be completely revised in order to ensure that that review of constitutionality does not remain under the

15 Ginsburg, Tom; HuQ, Aziz. How to save a Constitutional Democracy. Chicago: The University of Chicago Press, 2018, Graber, Mark, Levinson, Sanford, Tushnet, Mark, eds. Constitutional democracy in crisis? Oxford: Oxford University Press, 2018, Levitsky, Steven, Ziblatt, Daniel. How Democracies Die. New York: Crown, 2018, Przeworski, Adam. Crises of Democracy. Cambridge: Cambridge University Press, 2019.

16 Years ago, the emergency powers and military coups were important to "fast democratic breakdowns," which usually yielded to "a clearly authoritarian form of government." In contrast, the "slow erosion" of democracy would constitute the more common phenomenon of our time -a phenomenon that usually ends up with "some kind of competitive authoritarian structure" (Ginsburg, Tom; HuQ, Azzz. How to save a Constitutional Democracy. Chicago: The University of Chicago Press, 2018, p. 39). Summarizing a central part of their approach, Ginsburg \& Huq state: "In the last decade of the twentieth century, liberal democracy seemed to have triumphed everywhere. Yet today there is increasing concern that the form of democracy provides a façade for undemocratic behavior" (Ibid., p. 9).

17 Ibid., p. 43-4.

18 On the positive side, this dramatic scenario is forcing us to consider democratic alternatives that we should have taken seriously long time ago -alternatives that those of us who advocate for democratic dialogue have frequently defended. I am here thinking about citizens' assemblies; town meetings; and other forms of direct forms of democratic participation and deliberation (alternatives that fit perfectly well with the dialogic principle that says that the democratic dialogue should be carried out by "all those potentially affected", HABERMAS, JURGEN. Between Facts and Norms: Contributions to a Discourse Theory on Law and Democracy. Cambridge: MIT Press, 1996). 
exclusive control of the judicial apparatus. Also, in this way, the "alternatives to judicial invalidation" explored by Albert gain sense and force ${ }^{19}$; and the same happens with the "deliberation requirements" that he studies in Chapter $5^{20}$. On the other hand, distinctions such as the one that Professor Albert proposes, between amendments and dismemberments, need now be qualified or complexed, so to take into account the levels of citizen discussion on which they are based, or which they come to promote; etc. I shall come back to many of these points later. Meanwhile, let me begin the critical examination of the book, by first focusing on the crucial differentiation the author makes between "amendments" and "dismemberments".

\section{DISTINGUISHING BETWEEN AMENDMENTS AND DISMEMBERMENTS}

According to the Professor Albert, the distinction between "amending" and "dismembering" the Constitution represents the "foundational distinction" upon which his entire book is based ${ }^{21}$. He summarizes this distinction by stating that an amendment "keeps the constitution coherent with itself but a dismemberment marks a fundamental break with the core commitments or presuppositions of the constitution" 22 . A constitutional dismemberment -he suggests- "alters one or more of the constitution's essential features -a fundamental right, a load-bearing structure, or a core feature of the identity of a constitution". ${ }^{23}$ It "alters or fills the void that exist in the conventional theory of constitutional change between an amendment and a new actual constitution" 24 . The distinction -he assumes- may help constitutional designers to "create different procedures for amending the constitution and others for dismembering it" 25 . In different ways, the distinction between amendments and dismemberments has been revised and challenged by scholars of different provenience ${ }^{26}$. Herein, I want to suggest some additional problems that I find in this "foundational" distinction and its main implications.

19 Albert, Richard. Constitutional Amendments: Making, Breaking, and Changing Constitutions. Oxford: Oxford University Press, 2019, p. 222.

20 Ibid.,p. 204.

$21 \quad$ Ibid., p. 262.

22 Ibid., p. 262.

23 Ibid., p. 85.

24 Ibid., p. 85.

25 Ibid., 263.

26 Bernal, Carlos. On Constitutional Dismemberment. Yale Journal of International Law, Symposium: Constitutional Amendment and Dismemberment, 2018. Available in: https://www. yjil.yale.edu/2018/02/, LANDAU, DAVID. Rescuing the Unconstitutional Constitutional Amendment Doctrine: A Reply to Richard Albert. Yale Journal of International Law, Symposium: Constitutional Amendment and Dismemberment, 2018. Available in: https://www.yjil.yale.edu/2018/02/, Roznai, Yaniv. Constitutional Amendment and "Fundamendment": A Response to Professor Richard Albert. Yale Journal of International Law, Symposium: Constitutional Amendment and Dismemberment, 2018. Available in: https://www.yjil.yale.edu/2018/02/. 
i) An imperfect distinction. One initial thing I would suggest is that Albert's distinction between "amending" and "dismembering" the Constitution is not sufficiently clear. Consequently, his distinction may be unable to help us when trying to understand and classify some common phenomena within constitutionalism. Consider the following example (which was, by the way, the first case in which I thought when I wanted to "test" this "foundational" distinction), namely the remarkable wave of constitutional reforms that took place in Latin America during the first half of the $20^{\text {th }}$ Century. During those years, most constitutions in the region were modified in order to introduce one crucial change in the prevailing texts, namely a list of social, economic and cultural rights. This (usually long) list of social rights was added to the traditional -and liberal- Bill of Rights, which all those constitutions had already adopted. These changes inaugurated a new stage of regional constitutionalism: a period of so-called "social constitutionalism". The problem is that, depending on how one reads those reforms, they could be classified either as amendments or as dismemberments.

Recall that, for Albert, an amendment "properly defined [...] keeps the altered constitution coherent with its pre-change identity, rights, and structure"27, while a constitutional dismemberment "alters one or more of the constitution's essential features -a fundamental right, a load-bearing structure, or a core feature of the identity of the constitution" 28 -it "makes violence" to the constitution. Taking into account those criteria, how should one classify the social rights reforms? Were them amendments or dismemberments? Let me briefly explore both alternatives, using Professor Albert's favored criteria.

On the one hand -one could argue- the coming of "social constitutionalism" kept the altered constitutions coherent: those reforms did not "make violence" to the pre-existing constitutional order. In most cases, the old constitutions were preserved fundamentally intact, while just one, crucial aspect of them, was changed -and changed in a way that "improved" the previous documents without "destroying" them. Let me illustrate the specific situation I am thinking about through the specific example of Argentina's 1853 Constitution, and its 1957 reform. In 1957, Argentina promoted a constitutional reform, which implied the incorporation of article 14 bis. This was a long article, which transformed the 1853 constitution in a substantive way: through the incorporation of article 14 bis, the constitution became a "social", rather than a liberal constitution. ${ }^{29}$

27 Albert, Richard. Constitutional Amendments: Making, Breaking, and Changing Constitutions. Oxford: Oxford University Press, 2019, p. 84.

28 Ibid., p. 85.

29 Section 14bis. states "Labor in its several forms shall be protected by law, which shall ensure to workers: dignified and equitable working conditions; limited working hours; paid rest and vacations; fair remuneration; minimum vital and adjustable wage; equal pay for equal work; participation in the profits of enterprises, with control of production and collaboration in the management; protection against arbitrary dismissal; stability of the civil servant; free and democratic 
In a way -one could claim- this amendment (and here I quote Professor Albert) "continues the constitution-making project initiated at the founding" Precisely for this reason, nobody (no single legal authority or scholar) has ever read the 1957 reform as a "constitutional breakdown" or claimed that the old 1853 constitution resulted in that way "unmade"- even though the introduced change modified the "nature" of the constitution substantially. ${ }^{31}$

On the other hand, one could claim, the coming of "social constitutionalism" did represent a constitutional "dismemberment" -at least, if one took into consideration some other suggestions that are present in the book. Let me quote Professor Albert again. In his view, a "dismemberment" modifies the constitution in a substantive way "by remaking the constitution's identity, repealing or reworking a fundamental right, or destroying and rebuilding a central structural pillar of the constitution" 32 . So, what to say now about "social constitutionalism"? The fact is that, after the introduction of social rights, the old constitutions" "identity" was actually changed: the old "liberal" constitutions were transformed into "social" constitutions. Moreover, the list of "fundamental rights" was totally re-worked, and "a central structural pillar of the constitution" (the entire structure of rights) was substantially altered. This is to say, by taking Professor Albert's words seriously, one could end up stating one thing or the contrary, in what regards the changes introduced by incorporating social rights into the constitution.

The above example suggests that the book's "foundational distinction" between "amendments" and "dismemberments" is less clear than desired. Obviously, these imperfections become more significant when and if we want to use such distinction in order to ground the rest of our analysis -or a significant part of it (as the book does). In Constitutional Amendments, the distinction between the two categories is in fact crucial ("foundational") for a number of purposes, such as validating or challenging the validity of a certain reform; or suggesting different kinds of (judicial) controls depending on

labor union organizations recognized by the mere registration in a special record. Trade unions are hereby guaranteed: the right to enter into collective labor bargains; to resort to conciliation and arbitration; the right to strike. Union representatives shall have the guarantees necessary for carrying out their union tasks and those related to the stability of their employment. The State shall grant the benefits of social security, which shall be of an integral nature and may not be waived. In particular, the laws shall establish: compulsory social insurance, which shall be in charge of national or provincial entities with financial and economic autonomy, administered by the interested parties with State participation, with no overlapping of contributions; adjustable retirements and pensions; full family protection; protection of homestead; family allowances and access to a worthy housing."

30 Albert, Richard. Op. cit., p. 79.

31 I am bracketing the procedural problems that characterized the 1957 reform, which we do not need to consider for the purposes of this argument.

32 Albert, Richard. Constitutional Amendments: Making, Breaking, and Changing Constitutions. Oxford: Oxford University Press, 2019, p. 78. 
whether we were facing an amendment or a dismemberment. In any case, let me stop here for the moment, and turn to a different problem that I recognize in Professor Albert's book.

ii) Lack of critical power. Even though the author has, and at different points expresses, strong opinions on many of the subjects he studies in Constitutional Amendments (a summary of these opinions can be found in the last chapter of his book) it seems clear to me that the main point of the book was to present a very rich descriptive analysis of constitutional amendments (the "uncharted terrain"). Albert's choice is certainly irreproachable, although it may be insufficient for the study of the "use and misuse" of amendments, or the examination of the "validity" of a certain amendment (and the author dedicates numerous pages to the study of the "validity of amendments"): those evaluations require firmer normative grounds.

In particular, I would suggest, his work has insufficient critical bite, and in this sense may be unable to detect and challenge some of the most common deficiencies affecting modern constitutionalism. Consider, for instance, the following example, also coming from Latin Americas' constitutional history.

Between 1991 and 2005, ten Latin American countries reformed their constitutions in order to change the rules governing presidential re-election (and three changed them twice). In almost all those cases, the amendments brought with them less restrictive reelection rules ${ }^{33}$. Constitutional changes, at that time, were (in most cases) either directed at allowing presidential re-election, or at making immediate reelection possible (i.e., in Argentina, Brazil, Colombia, Dominican Republic, Ecuador, Peru, Venezuela). Not surprisingly, in many occasions, those changes came to favor the incumbent president. In other words, those constitutional reforms were directed, almost exclusively, to benefit the political class who promoted them. In fact, many of these changes did not reserve even the slightest space to matters of common, public interest (say, favor future generations or develop a new collective project). Those reforms should be considered the expected and unfortunate product of our degraded and eroded democracies: they offer us a clear example of the way in which the traditional controlling devices of the constitution have been "captured" and used by elites and interest groups, for their own benefit. In the face of such pathologies, the distinction between "amendments" and "dismemberment" does not come to our help. Perhaps, after investigation, we recognize that the majority of those reforms represented amendments that were in line with a long history -an unhappy tradition- of

33 Landau, David. Constituent Power and Constitution-Making in Latin America in Lerner, Hanna, Landau, David. eds. Comparative Constitution-Making, Edward Elgar Press, 2019, Negretto, Gabriel. Making Constitutions. Cambridge: Cambridge University Press, 2013, GarGARELla, RoBerto. Latin American Constitutionalism. Oxford: Oxford University Press, 2013. 
erratic constitutional reforms. Or not. But, again, in those circumstances it may be unhelpful to engage into those questions and disquisitions ("Was this reform a proper amendment, or was it, instead, a dismemberment?"). In those difficult circumstances, we need to be able to explain constitutional designers why certain institutional reforms (i.e., a reform directed at allowing presidential reelection; or -more generally- reforms that tended to "seriously [...] curtail the operation of those political processes" -as it was maintained in Carolene Products' famous footnote 4) should be subjected to more exacting collective scrutiny -and perhaps confronted through political means.

The point is that Professor Albert's approach does not seem to be particularly sensitive to the problem of "democratic erosion" -in other words, it does not appear to be well prepared to detect and critically examine these developments, which represent the most serious threat faced by contemporary democratic systems. Following James Madison's teachings, my suggestion would then be: we should approach to questions of institutional design by having in mind the most serious risks affecting our public life (i.e., the problem of "factions", during the "founding period"; the problem of "democratic erosion", in our time). More specifically, we need to be able to understand and explain why, at this time, certain constitutional amendments should be resisted.

iii) The question about judicial review of constitutional amendments. A third question that I want to raise concerns the place that Albert's book reserves to the judicial review of constitutional amendments. My point is, again, that in a context marked by "democratic erosion", our analysis should not be neutral -it should not be the same kind of analysis we could have developed when we assumed that the system of "checks and balances" was functioning quite well. In other words, at this time, our presumption should not be that the branches will tend control the excesses of each other (as if the different branches had similar powers/ as if the members of the different branches had opposite interests), but rather that they will tend to serve each other (given that one branch gained much more power than the others/ given that the members of different branches had too many interests in common). In fact: what reasons do we have, at this time, to be deferent towards the judiciary, when the "separation" between the political and judicial branches has been undermined? Why should we trust, in principle, judicial decisions related to the separation of powers, when (the rule seems to be that) many of the most prominent members of the judiciary seem to share the interests of the Executive Branch?

Let me illustrate the kinds of situations I am thinking about by resorting, again, to an example derived from recent Latin American history. The case that I want to consider comes from Bolivia 2016, when then President Evo Morales lost a referendum that he himself had promoted, in order to modify the Constitution and thus gain authorization to run for office for a fourth term. Remarkably, the Plurinational Constitutional Court, after a demand set by 
Morales' Movement to Socialism (MAS) party, decided, on a November 20th, 2017 unanimous verdict ${ }^{34}$ that limits barring elected authorities from seeking re-election indefinitely, entered in conflict with the American Convention on Human Rights and thus violated human rights. In the words of Macario Lahor Cortez, head of the Plurinational Court, "All people that were limited by the law and the constitution are hereby able to run for office, because it is up to the Bolivian people to decide." So, what we have here is a failed political attempt to amend the Constitution, which was finally obtained through a (shameful) judicial decision, promoted by a (politically dependent) Constitutional Court.

Of course, I do not mean to imply that these situations represent the dominant pattern in our time, or even in Latin America. What I suggest, instead, is that these kinds of examples do not anymore constitute the extreme exception -the exception that may only emerge in exotic countries or bizarre circumstances. In this new political context defined by "democratic erosion", we should not act as if we were living in the ideal world of the "checks and balances". In other words, we should not develop our institutional analysis (our "new topography") by having in mind the "old pictures" of the explored territory.

In chapter 5 of his book, Professor Albert refers, for instance, to the "many institutional design options" that constitutional designers "have at their disposal if they wish to confer upon courts the power to review constitutional changes" 35 . Now, if we took into consideration the serious institutional problems that we explored in previous sections, we should be more cautious about those kinds of recommendations. Being aware of the "dramas" of our time, my suggestion would be to help constitutional designers to prevent the development of new and foreseeable institutional calamities (again, in the same way that Madison helped his generation to prevent the threats posed by factions). Many of those "institutional design options" at our "disposal" may result unsuitable or simply inadvisable at our time -and we must able to state it, loud and clear.

\section{CAN THE DOCTRINE OF UNCONSTITUTIONAL AMENDMENTS SAVE US?}

In Chapter 5 of his book, Professor Albert critically examines the influential doctrine of unconstitutional constitutional amendments (DUCA), as a potential response to the problems posed by illegal amendments. In line with the previous analysis, I would recommend being more cautious about this significant doctrine and its noble promises.

According to the doctrine of unconstitutional amendments (and here I will follow Professor Albert's own description of it) "the people," in charge of the "constituent power" has created a constitution, and also "constituted

34 TCP Sentencia Constitucional Plurinacional n. ${ }^{\circ} 0084 / 2017$.

35 Albert, Richard. Constitutional Amendments: Making, Breaking, and Changing Constitutions. Oxford: Oxford University Press, 2019, p. 264. 
powers" who are required to act in the people's name consistent with the constitution. Taking into account those assumptions, then "the judicial act of striking down a transformative change" can be deemed a justifiable intervention to safeguard the terms of the original bargain approved by the people" 36 . Despite representing "an example of what Ran Hirschl has labeled the "judicialization of mega-politics" -he suggests- such judicial decision could not be deemed offensive to democracy ${ }^{37}$. Rather, it must be recognized as "a triumph of democracy" 38 . To declare a constitutional amendment unconstitutional may represent a way of ensuring that the will of the people, expressed in the constitution, prevails against the transient will of their representatives.

Now, what would justify the reasoning behind the DUCA? More particularly: i) what would justify the sharp distinction upon which the doctrine is based (namely the distinction between the "original" and "derived" will of the people); and ii) what would justify the interpretative powers and capacities that the DUCA attributes to the judicial branch? In the particular version of the doctrine that Professor Albert examines in his book -basically, Yaniv Roznai's ${ }^{39}$ view - the justificatory work is based on Sieyes' controversial distinction between "constituent" and "constituted" powers ${ }^{40}$ This original distinction, however, is extremely polemical and -not surprisingly- tends to translates its own problems to the doctrine of unconstitutional amendments, as we shall explore. ${ }^{41-42}$

36 Ibid., p. 217.

37 Ibid., p. 218.

38 Ibid., p. 217.

39 RoznaI, Yaniv. Unconstitutional Constitutional Amendments, Oxford: Oxford University Press, 2017.

40 Thus, as it was presented in 1789 by the Abbe Sieyes, in his political pamphlet ' $Q u$ 'est-ce qui le tier-etat?' (SieYes, Emmanuel. Emmanuel Joseph Sieyes: The Essential Political Writings (Studies in the History of Political Thought. Brill: Lam Edition, 2014.). In my view, the entire theoretical machinery -the "machinery" that is required in order to maintain what the DUCA maintains- had been articulated centuries ago in the American context. In my view, the logic behind the doctrine of unconstitutional amendments is basically identical to the one that Alexander Hamilton famously introduced in Federalist Papers 78. At that time, Hamilton did the same two things that the doctrine of unconstitutional amendments wants to do, namely i) justify the special force and particular character of the constitution through a "democratic" argument (in this way, the constitution is identified with the will of the people); and ii) justify the judicial role in invalidating infra-constitutional decisions in the name of the constitution and democracy. Now, if we accept that the reasoning behind both views is basically similar, both the Hamiltonian approach and the logic of the doctrine of unconstitutional amendments end up sharing similar problems, beginning from the fact that they presume a rather weak understanding of democracy.

41 Bernal, Carlos. On Constitutional Dismemberment. Yale Journal of International Law, Symposium: Constitutional Amendment and Dismemberment, 2018. Available in: https://www. yjil.yale.edu/2018/02/

42 For instance, as Conall Towe has recently put it, "constituent power theory cannot justify doctrines of implicit constitutional unamendability because it is inherently paradoxical. Under the constituent/constituted distinction, powers of constitutional amendment exist as the latter - they flow from the constitution and are thus limited by it. However, if constituent power is 
As far as I see it, the theoretical problems affecting the DUCA appear at both the above-mentioned levels. On the one hand, there seems to be an extremely weak connection between what we may designate as the "absolute" or "sovereign" "will of the people" and the will of those politicians who actually write a constitution -a problem that seems aggravated the closer we examine how constitutions tend to be written. ${ }^{43}$ Usually, constitutions are written by just a few, who claim to represent the people at large. This situation generates all the obvious risks that were for instance studied by Jon Elster in his book Ulysses Unbound, which he summarized in the idea that "in politics, people never try to bind themselves, only to bind others". ${ }^{445}$ Recall, for instance, the case of the American "founding fathers", when they shielded the issue of slavery in the Federal Assembly, or -more recently- the case of Spain, when the political class decided to entrench "the entire slate of rules concerning the Crown" ${ }^{46}$. In such situations (and the examples that I chose refer to two of the most significant constitutional assemblies in the World's history) one does not easily recognize the presence of the "sovereign will" of the people, but rather finds something quite different, which very much resembles the particular interests of the members of the convention themselves. This is why -I submit- those decisions -like many other similar ones, coming from similar, foundational constitutional assemblies- should be read, more and more, with prudence and skepticism, if not directly with some suspicion.

On the other hand, there are no reasons for simply assuming the existence of a relevant connection between the meaning of the constitution (whatever

truly an all-powerful extra-legal force without confine, then why can it not be exercised through amendment process? Logically, this is a contradiction - either the constituent power is absolute (and can be exercised through the amendment process) or it is not (and thus cannot be exercised through the amendment process). If the subjects of a constitution want to amend a part of it, then why must they make a new Constitution instead of using the amendment process?" (Towe, Conall. Constituent Power and Doctrines of Unconstitutional Constitutional Amendments. Trinity College Law Review's Joint Edition in Constitutional Law Series, 2019.).

43 Let me make clear, however, that a dialogic approach to democracy neither requires nor implies a repudiation of the idea of an extraordinary and unlimited "constituent' power" (a "constituent power" in the hands of "the people," representing "an extra-legal power with no confines"). In fact, something like the "ideal speech situation", presented by Jurgen Habermas in his work, may play a similar role, as a regulative idea that helps us to critically examine the value of actual constitutional agreements.

44 Elster, Jon. Ulysses Unbound. Cambridge: Cambridge University Press, 2000, p. ix.

45 Moreover, for those of us who distinguish a decision as "democratic" only when it has been the result of a "dialogue" among "all those potentially affected", most Constitutions do not rank well as "democratic acts", even in the case the document has been ratified (after the work of the Constituent Assembly) by majority vote: first, such processes of popular ratification are usually very poor in terms of collective deliberation, and second -and most significantly- they force people to limit their judgement to just say "yes" or "no" -"yes" or "no" to the hundreds of topics and problems presented by a constitutional reform.

46 Albert, Richard. Constitutional Amendments: Making, Breaking, and Changing Constitutions. Oxford: Oxford University Press, 2019, p. 192. 
that meaning is) and the peculiar reading that judges may present about the constitution. And this would be so for numerous reasons, including problems related to the democratic legitimacy of the judiciary $;{ }^{47}$ the presence of infinite difficulties related to constitutional interpretation; ${ }^{48}$ motivational problems that the book does not examine (i.e., why would judges be motivated to act in the desired way?); and also functional problems, such as the ones that Professor Albert aptly recognizes in his book..$^{49}$ In sum, two of the main pillars upon which the DUCA is based (related to the "sovereign will of the people" and the powers/capacities of the judicial branch) seem to be much more fragile than required..$^{50}$

Things become more promising, however, if -instead of simply following the "doctrine of unconstitutional amendments"- we focus on the "alternatives to (judicial) invalidation" that Professor Albert explores at the end of Chapter 5. At that point, Albert proposes (but unfortunately does not develop) "alternative" forms of judicial review of amendments, "built on the theory of democratic dialogue". According to such alternatives, a court could "declare an amendment incompatible with its own reading of the constitution, though the effect of its declaration would be purely advisory with no binding legal consequence" 51 . This possibility (which he describes as "catalytic, not obstructive") would "put judges into conversation with reformers to invite them to have a second look at the amendment" ${ }^{52}$ This alternative to invalidation -Professor Albert suggests- would be a variation on the design of the

47 The problems that appear in this respect are numerous, and have been routinely examined by legal scholars, at least since the emergence of Alexander Bickel crucial study. As Bickel famously stated, when courts declare a law invalid, what in fact happens is that they thwart "the will of the representatives of the actual people of the here and now," thus exercising control "not in behalf of the prevailing majority, but against it" (BICKEL, AleXANDER. The Least Dangerous Branch. Conn: Yale University Press, 1962, p. 17).

48 To say the least: in the context of plural, multicultural societies, marked by the "fact of disagreement", why should judges play such a decisive (if not final) role, in the resolution of our most fundamental, constitutional disagreements? (WALDRON, JEREMY. Law and Disagreement. Cambridge: Cambridge University Press, 1999).

49 For instance, when he states: "the doctrine of unconstitutional constitutional amendment can be useful in the defense of democracy, but it is susceptible to misapplication, just as any other judicial doctrine", Albert, RichaRd. Constitutional Amendments: Making, Breaking, and Changing Constitutions. Oxford: Oxford University Press, 2019, p. 221.

50 It is important to note that the problem we face is not one that may disappear by saying, for instance, that the more the constituent assembly resembles the primary constituent power, the less it should be constrained, and vice versa. The problem is "categorical". More precisely, fundamental constitutional matters need to be decided, examined and re-examined through collective dialogic agreements. And this is not something that the "doctrine" gives us: judicial decisions cannot reproduce or "mimic", in any significant way, a collective conversation among the people -this is to say, a collective dialogue where the citizenry plays the central role.

51 Albert, Richard. Constitutional Amendments: Making, Breaking, and Changing Constitutions. Oxford: Oxford University Press, 2019, p. 223.

52 Ibid., p. 223. 
United Kingdom Human Rights Act and the New Zealand Bill of Rights Act for the judicial review of statutes ${ }^{53}$.

As anticipated, I tend to agree with Professor Albert in what concerns this "alternative to invalidation". Nevertheless, I want to add a minor comment about it: for a dialogic view, the "conversational" review of amendments should not remain restricted to a dialogue between the different branches of government, as in the model that seems to be here proposed. By contrast, the dialogue that courts need to promote must include, in a special and central way, the participation of the entire citizenry. In other words, a dialogue that is, in the best case, restricted to the different branches of power, or a dialogue between "technical" and weekly representative public officers (like a dialogue between elites), does not satisfy the requirements of a robust dialogic theory. In our plural, multicultural societies, a proper collective conversation needs to have the people at large at the center and as the main actor-particularly when democracies are affected, as our democracies are, by a profound crisis of representation.

4. CODA: DEMOCRACY AND A

"HIERARCHY OF CONSTITUTIONAL IMPORTANCE"

In this book, like in previous work, Professor Albert explored alternatives to codified unamendability, through an escalating system of constitutional change. This system would provide special protection to fundamental constitutional values by requiring significant procedural efforts to alter them ${ }^{54}$. He also suggests "codifying an escalating structure of restricted amendment pathways to make some constitutional rules harder to amend than others yet without insulating any of them from formal change" ${ }^{55}$. The proposal, he claims, has at least two positive benefits. First, it "achieves the same expressive function as unamendability, identifying for all to see what is thought to be most integral in the polity." Second, the system "needs not limit itself to two levels of amendment difficulty" ${ }^{\prime \prime 6}$. What emerges -he concludes- is a "hierarchy of constitutional importance, with some parts or principles of the constitution assigned to amendment procedures and others to dismemberment procedures" ${ }^{57}$. From the viewpoint I have defended in previous pages, Albert's proposal sounds also interesting. As he himself remarks, the escalating system

53 Gardbaum, Stephen. The New Commonwealth Model of Constitutionalism. Cambridge: Cambridge University Press, 2013.

54 Albert, Richard. Constitutional Handcuffs. Arizona State Law Journal 42: 663, 2010, Albert, Richard. Constitutional Amendment and Dismemberment. 43 Yale J. Int'l L. 1, 2018.

55 Albert, Richard. Constitutional Amendments: Making, Breaking, and Changing Constitutions. Oxford: Oxford University Press, 2019, p. 201.

56 Ibid, p. 201.

57 Ibid., p. 263. 
results in principle attractive from a democratic perspective: the assumption is that codified unamendability improperly limits the range of options that a reasonable democratic community should have.

Now, what if constitutional amendment rules were not tiered? In recent work, Albert has suggested the adoption of a "mutuality rule" that requires that the procedure to be used to change fundamental constitutional values should be basically equivalent to the procedure that brought the existing constitutional norms into being. In addition, he proposes a "constructive" and advisory, rather than prohibitive judicial role, in the analysis of those amendments ${ }^{58}$. Contrary to what Professor Albert maintains, David Landau finds these alternatives to be closely related to the doctrine of unconstitutional constitutional amendments that he defends -he actually claims that they are "fairly close relatives" 59 . In Landau's words, this doctrine "allows courts to develop a relatively crude form of tiering inferred from the constitution by effectively requiring that certain changes to the "basic structure" or "core values" go through a constitution-making process, rather than using the normal amendment rules" ${ }^{\circ}$. In that sense, "it often satisfies (Albert's) mutuality criterion" 61 .

From the perspective that I have here defended -and considering the context of political elitism, "democratic erosion", and "democratic capture" that we have described in previous pages- none of those ideas results particularly promising. In fact, for political leaders (or members of a political elite) who have managed to gain control of the institutional structure, the proposed requirements seem extremely easy to overcome -almost a joke. Within the existing and restrictive democratic processes, the gathering of a Constitutional Convention or the call for a ratifying plebiscite seems does not appear as serious problems. The same goes, again, for the doctrine of unconstitutional constitutional amendments ${ }^{62}$, and other theories that rely on the capacities of the judicial branch. In this respect, examples like the one of Colombia and the Constitutional Court's decision that prevented Alvaro Uribe's re-election seem

58 Albert, Richard. Constitutional Amendment and Dismemberment. 43 Yale J. Int'l L. 1, 2018, LANDAU, David. Rescuing the Unconstitutional Constitutional Amendment Doctrine: A Reply to Richard Albert. Yale Journal of International Law, Symposium: Constitutional Amendment and Dismemberment, 2018. Available in: https:/www.yjil.yale.edu/2018/02/.

59 LANDAU, DaVID. Rescuing the Unconstitutional Constitutional Amendment Doctrine: A Reply to Richard Albert. Yale Journal of International Law, Symposium: Constitutional Amendment and Dismemberment, 2018. Available in: https://www.yjil.yale.edu/2018/02/.

60 Ibid.

61 Ibid.

62 LANDAU, DaVID. Rescuing the Unconstitutional Constitutional Amendment Doctrine: A Reply to Richard Albert. Yale Journal of International Law, Symposium: Constitutional Amendment and Dismemberment, 2018. Available in: https://www.yjil.yale.edu/2018/02/, Dixon, Rosalind \& Landau, David. Tiered Constitutional Design, George Washington Law Review, vol. 86, 2017. 
more the exception than the rule ${ }^{63}$. In Latin America at least, and particularly in the context of "captured" democracies, Supreme or Constitutional Courts tend to become the main ally of the President, as the shameful examples of Venezuela, Ecuador or, more recently, Bolivia (see above), demonstrates.

From the perspective of a robust dialogic theory, historically situated, what should actually matter is the depth and breadth of the constitutional agreement- more precisely, the inclusive and deliberative character of the collective, constitutional accord, and not the fact that the changes complied with certain legal formalisms that seem easy to obtain in the context of our degraded democracies. ${ }^{64}$ The regulative ideal that I have here proposed would help us to abandon many of the presumptions that distinguish Professor Albert's work -either presumptions in favor of the stability of the constitutional agreement, or presumptions in favor of the original constitutional agreement (particularly, but not only, in light of the limited democratic legitimacy that characterizes many of the old constitutions that are still in place).

In the previous pages, I took some initial steps in the exploration of Professor Richard Albert's book Constitutional Amendments, and critically examined some of the points I considered most salient in this work. I do not want to conclude these comments, however, without congratulating the author again for the magnificent work he has done, which undoubtedly establishes a "before and after" in the study of constitutional amendments.

\section{BIBLIOGRAPHY}

Albert, Richard. Constitutional Handcuffs. Arizona State Law Journal 42: 663, 2010.

Albert, Richard. How a Court Becomes Supreme. 77 Md. L. Rev.18, 2017.

Albert, Richard. Constitutional Amendment and Dismemberment. 43 Yale J. Int'l L. 1, 2018.

Albert, Richard. Constitutional Amendments: Making, Breaking, and Changing Constitutions. Oxford: Oxford University Press, 2019.

Albert, Richard. Author Interview: Constitutional Amendments: Making, Breaking, and Changing Constitutions, 2019. Available in: https://blog-iacl-aidc.org/just-published/2019/10/15/author-interview-constitutional-amendments-making-breaking-andchanging-constitutions.

Bernal, Carlos. On Constitutional Dismemberment. Yale Journal of International Law, Symposium: Constitutional Amendment and Dismemberment, 2018. Available in: https://www.yjil.yale.edu/2018/02/.

Bickel, Alexander. The Least Dangerous Branch. Conn: Yale University Press, 1962.

63 Decision C-141 of 2010.

64 Worse still, once produced, those formal legal rules claim to be both legal and legitimate, in agreement with the rule of law and respectful of democracy, when they are none of those things. 
Bohman, James. Public Deliberation: Pluralism, Complexity, and Democracy. Cambridge: MIT Press, 1996.

Bohman, James, Rehg, William (eds.). Deliberative Democracy. Cambridge: mit Press, 1997.

Canales, Mariana. Why Does Constitutional Amendment Design Matter? International \& Comparative Law. JOTWELL. Review of Richard Albert, Constitutional Amendments, 2020. Available in: https://intl.jotwell.com/why-does-constitutional-amendment-design-matter/

Dixon, Rosalind, Landau, David. Tiered Constitutional Design, George Washington Law Review, vol. 86, 2017.

Dworkin, Ronald. In praise of theory. Arizona State Law Journal 353, 1997.

Elster, Jon (ed.) Deliberative democracy. Cambridge: Cambridge University Press, 1998.

Elster, Jon. Ulysses Unbound. Cambridge: Cambridge University Press, 2000.

Elster, Jon., Slagstad, Rune. Constitutionalism and Democracy. Cambridge: Cambridge University Press, 1988.

Gardbaum, Stephen. The New Commonwealth Model of Constitutionalism. Cambridge: Cambridge University Press, 2013.

Gargarella, Roberto. Latin American Constitutionalism. Oxford: Oxford University Press, 2013.

Ginsburg, Tom; HuQ, Aziz. How to save a Constitutional Democracy. Chicago: The University of Chicago Press, 2018.

Graber, Mark, Levinson, Sanford, Tushnet, Mark, eds. Constitutional democracy in crisis? Oxford: Oxford University Press, 2018.

Gutmann, Amy, Thompson, Dennis. Why Deliberative Democracy? Princeton: Princeton University Press, 2004.

Habermas, Jürgen. Between Facts and Norms: Contributions to a Discourse Theory on Law and Democracy. Cambridge: MIT Press, 1996.

Habermas, JÜRgen. “Interview with Jurgen Habermas," in Bachtiger, AndRe, DryzeK, John et al., The Oxford Handbook of Deliberative Democracy, Oxford: Oxford University Press, 2018.

Holmes, Stephen. "Precommitment and the Paradox of Democracy," in Elster, Jon, Slagstad, Rune. Constitutionalism and Democracy. Cambridge: Cambridge University Press, 1988.

Landau, David. Rescuing the Unconstitutional Constitutional Amendment Doctrine: A Reply to Richard Albert. Yale Journal of International Law, Symposium: Constitutional Amendment and Dismemberment, 2018. Available in: https://www.yjil.yale.edu/2018/02/.

Landau, David. Constituent Power and Constitution-Making in Latin America in Lerner, Hanna, Landau, David. eds. Comparative Constitution-Making, Edward Elgar Press, 2019.

Levitsky, Steven, Ziblatt, Daniel. How Democracies Die. New York: Crown, 2018. 
Negretto, Gabriel. Making Constitutions. Cambridge: Cambridge University Press, 2013.

Nino, Carlos. The Constitution of Deliberative Democracy. New Haven: Yale University Press, 1997.

Przeworski, Adam. Crises of Democracy. Cambridge: Cambridge University Press, 2019.

Roznai, Yaniv. Constitutional Amendment and "Fundamendment": A Response to Professor Richard Albert. Yale Journal of International Law, Symposium: Constitutional Amendment and Dismemberment, 2018. Available in: https://www.yjil.yale.edu/2018/02/.

Roznai, Yaniv. Unconstitutional Constitutional Amendments, Oxford : Oxford University Press, 2017.

Sieyes, Emmanuel. Emmanuel Joseph Sieyes: The Essential Political Writings (Studies in the History of Political Thought). Brill: Lam Edition, 2014.

Towe, Conall. Constituent Power and Doctrines of Unconstitutional Constitutional Amendments. Trinity College Law Review's Joint Edition in Constitutional Law Series, 2019.

Waldron, Jeremy. Law and Disagreement. Cambridge: Cambridge University Press, 1999.

\section{Judicial decisions}

Plurinational Constitutional Court of Bolivia. Sentencia Constitucional Plurinacional n. ${ }^{\circ} 0084 / 2017$

Colombian Constitutional Court. Decision C-141 of 2010. 